\title{
One clock fits all?
}

\section{Time and imagined communities in nineteenth-century Germany ${ }^{*}$}

Oliver Zimmer

"The railways, some have claimed, act as large national clocks." This was how Gustav Schmoller, the Heilbronn-born political economist, in 1873 judged the impact of the Eisenbahn on everyday life and culture. It was by no means unusual to associate the railways with the forward march of national time, least of all in the nineteenth century. Most educated contemporaries, ranging from state mandarins and railway experts to municipal officials and business people, described the railways as a time-machine. ${ }^{2}$ What was unusual about Schmoller's observation was that, in presenting his judgement as a view held by others, he sounded an implicit note of caution. As far as he was concerned, only time could tell.

One can think of various reasons why Schmoller remained somewhat cautious on the prospect of a German standard time. His methodological preference for inductive reconstruction over deductive speculation may have provided one reason; his hailing from the federalist Württemberg a second; his skepticism about technological determinism a possible third. Whatever the reasons behind the eminent social reformer's reluctance to overload the railways with too much expectation, the next three decades would prove him right. What this period of German history sets into relief is that official (standard) time and lived (social) time pertain to different rhythms of life, even if their relationship became closely intertwined as the nineteenth century progressed. In this regard, Germany undoubtedly formed part of a broader tendency, one that manifested itself in other parts of Europe and beyond.

In spite of this broad commonality, Germany represents an extremely fertile case for an investigation of modern time culture. Much of this fertility derives from German- 
style intricacies concerning the adoption of a national standard time. After a protracted debate on this issue, in 1893 mitteleuropäische Zeit (MEZ in brief) was introduced by imperial legislation. By virtue of this legislative act, Germany acquired a time referent bearing on the whole of national life. ${ }^{3}$ Just over a year before the reform entered into force on 1 April 1893, the imperial railway authorities, wary of public resistance (particularly in Prussia), had decided to restrict MEZ to the railways' internal operations (innerer Betrieb). ${ }^{4}$ Having completed its one-year test run, the new Einheitszeit was subsequently extended to the railways' external operations (äusserer Betrieb). Now MEZ (set to the mean time of Greenwich: GMT in short) was displayed on the clocks that passengers caught sight of as they approached a railway station, while villages, towns and cities were encouraged to adopt it as the time of public life (Zeit für das bürgerliche Leben). At that point railway staff operating between Prussia's eastern borderlands and the Rhineland province must have breathed a sigh of relief, as henceforth all railway clocks (including the chronometers carried by train guards and station staff) could be set to a single time. ${ }^{5}$

Crucially, German time reform took place in a context of competitive comparisons and narrowing gaps. One such gap was domestic - for, in a sense, the evolution of a national time standard is a story of the North catching up with the South: In the southern states, standard time, set to the local mean time of a major city (Munich, Stuttgart, Karlsruhe and Ludwigshafen am Rhein), had been customary since the 1850s. Having operated regional standard times for several decades, political authorities in the South (as well as Alsace-Lorraine) introduced MEZ already on 1 April 1892. They also encouraged villages and towns to adopt it for public life as well - just as they had done when they had introduced standard times in the 1850 s and 1860 s. Their decision left 
Prussia (where the reluctance of making railway time the Zeit für das bürgerliche Leben remained marked) little choice but to follow suit. ${ }^{6}$ How his population had been faring with the new time regime, the Prussian envoy desired to know from a Württemberg minister in September 1892. Everything had gone smoothly, came back the reply from Stuttgart. $^{7}$

The other gap concerning time reform - more perceived than real, but exerting a powerful impact on both the debate and reality of German time reform - was international: Imperial Germany adopted GMT-based zone time after Britain (1848), the United States (1883) and Austria-Hungary (1890-93), but before Switzerland (1894), Denmark (1894), Norway (1895), and Sweden (1900), with Italy also converting to zone time in 1893 . That is to say, there simply was no dominant pattern; Germany formed part of a larger pack. If one had to identify a laggard in continental Europe, it would have to be France: After a long-standing battle with Britain over global temporal hegemony, the Third Republic moved to GMT in 1911, preferring to call it "l'heure de Paris moins 9 minutes et 21 secondes." And if one had to name a pace-maker, it would have to be Britain. ${ }^{8}$

Yet while these disparities were of little concern to most Germans, they mattered greatly to those who saw their country engaged in a series of international struggles; for it was these vocal reform-minded milieus that dominated the national debate on time reform, particularly after unification. ${ }^{9}$ How could a politically and economically powerful country such as Germany be so reluctant to come together in time - the Germany that had become a nation-state in 1871, and whose railways had gained such a central role since the 1860 s; the society that had benefited from a Customs Union founded in $1834 ?^{10}$ Why did the rigid separation of local time from railway time prevail 
for longer there than in several other countries? These are some of the questions that advocates of reform both within and without Germany posed in the last third of the nineteenth century.

When it comes to investigating time as a social experience and practice, however, these questions prove less than productive. Informed by nationalist narratives of progress, they frame the development of time cultures in terms of a series of modernist teleologies and dichotomies - as if, that is, the parallel existence of different temporal regimes (local versus national or North versus South, say) signified backwardness; as though that plurality formed an obstacle to the nation reaching its true potential. This article adopts a different approach. Instead of reconstructing time reform as a process of cultural imposition and institutional integration, it explores how a modern time culture evolved at the intersection of lived time and linear clock time.

Such an exploration is not made easier by the lack of in-depth research on time culture in nineteenth-century Germany, of the kind now available for many European and extra-European societies. ${ }^{11}$ All we have are a series of summaries of the familiar story of time reform culminating in the imperial law of 1893 . Tucked away for the most part in historical syntheses of one kind or another, most treat Helmuth von Moltke's 1891 address to the Reichstag as a decisive turning point. In this masterly speech, the legendary general urged the German public to endorse a national Einheitszeit on grounds of military strategy and civilizational progress. Thanks to this intervention, Moltke emerged as the foremost champion of German standard time, with many contemporaries as well as latter-born historians depicting him as a voice of progress in a temporal landscape marked by particularism. ${ }^{12}$ 
Within the rich international historiography on time, an influential interpretation (one that echoes the voices of nineteenth-century reformers) describes the worldwide shift towards national standard times as a function of modernity. One of the central requirements of an integrated nation-state under conditions of industrial capitalism, so this argument runs, is the rise of a national master clock. ${ }^{13}$ In a particularly strong version of this argument, Wolfgang Schivelbusch has called the railways the "destroyer of experiential space and time." ${ }^{, 14}$ In stark contrast to these functionalist interpretations of railway time, some cultural historians have stressed the diversity of temporal landscapes; here standard time merely adds another layer to a multiplicity of temporal rhythms. Scholars arguing in this vein have sometimes rejected the concept of modernity altogether, insisting that in the nineteenth century everyone fashioned their own modernity, so to speak. ${ }^{15}$

There are problems with these interpretations. Both downplay the tensions accompanying time harmonization. Both marginalize the fact that contemporaries (depending on their Sitz im Leben and point of view) experienced time reform as a project of either civilization or subjugation. No romantic mindset is needed to recognize that the cognitive and emotive pressures that time reform exerted on individuals and communities could be profound. Yet different temporal regimes rarely proved mutually exclusive. More often than not, lived time and standard time stood in a relation of tension to one another: If the notion of the all-transformative master clock amounts to a modernist myth, the view of the nation as a room filled with multiple timepieces ticking away happily represents somewhat of a cop out. ${ }^{16}$

This essay advances an interpretation that can hopefully serve as a point of departure and debate for future research on the evolution of time cultures in Germany 
and elsewhere. It starts from the recognition that railway communication relied on linear time, a universal epistemology that could (pending a sufficiently powerful technology) make everything happen all at once. ${ }^{17}$ Marx was right: If everything were to be synchronized the world over, locations and communities would melt into air. ${ }^{18}$ For railway time meant decontextualized time; its implementation threatened to flatten meaningful temporal landscapes. In practice, however, humans made time. Placemakers that they are, individuals and communities did not merely resist clock time, they assimilated it and put abstract time back in its place. In this way, they made time tangible and emotionally accessible. Communities take shape when time is attached to a specific location - be it in a nation, region, locality or professional society. ${ }^{19}$

The essay's focus is on the accommodations that German contemporaries made between different ("old" and "new) ways of talking and utilizing time, and on how they relocated a linear time, one that had no particular location, to suit their own individual and collective needs as they judged them. It examines two central ways in which Germans relocated abstract time, which are discussed in separate sections. The first (TALKING CLOCKS) investigates how Germans debated the merits and drawbacks of making railway time the time of public life. Here nationalism came to play a central role in the relocation of linear time. The second, slightly longer, section (ADJUSTING CLOCKS) investigates how time reform altered Germans' relationship to clocks as material objects telling the time. This shows that where standard time was confined to the railways' internal operations (as was the case in Prussia right up to 1893), pragmatism in relation to temporal accuracy and punctuality often prevailed. It also shows how individuals concerned with obtaining the "right time" used familiar clocks to assimilate the linear time displayed (for example) by their station clock, thereby 
turning it into something more tangible. In other words, and most importantly, the essay shows that clock time goes much deeper than standard time. The brief conclusion offers some reflections on the role of the station clock in calibrating modern times.

\section{Talking Clocks}

Of the foreign voices on global time reform attracting international attention, few counted more than Britain's Astronomer Royal, W.H. M. Christie. As he explained to a London audience in 1884, everywhere increased mobility had necessitated greater accuracy of time to regulate "the hours of labor, sleep, and the times for meals." Commercial interaction now often involved "different communities separated by distances which may range from a few miles to half the circumference of our globe." The first response to increased speed and widened space had been the introduction of solar mean time in the early nineteenth century. Yet, at least in England, solar mean time had marked but a brief interlude. By the 1840 s it had been replaced by GMT, which in 1884 (when it was adopted as Britain's legal time) had become the global time standard. As Christie summarized the British experience: "The railways carried London ... time all over the country, and thus local time was gradually displaced. The public soon found that it was important to have correct railway time, and that the discordance between the sun and the railway clock was of no practical consequence. For some years both the local and the railway times were shown on village clocks by means of two separate minute hands, but the complication of the dual system produced inconvenience, and local time was gradually dropped." ${ }^{20}$ In this way, Christie reminded his audience, Britain had put itself in the lead. While the railways of France, Austria, Italy and Sweden ran on standard time centered on a capital city, the public life of those countries 
still followed local time, with travelers having to switch from one time to another as they approached a railway station. Whereas the railway companies in much of continental Europe lived in one temporal universe, the public, or at least its travelling portion, had to live in two. ${ }^{21}$ Whoever ignored the difference between local and railway time risked either missing their train or arriving at the station too early. Only in Britain had railway time absorbed local time. ${ }^{22}$

Yet only in Germany, Christies reassured his audience, were people shielded from railway time altogether. Only there, "under the influence of certain astronomers," did railway staff communicate with passengers exclusively in local time. Only there did external station clocks tell the time of the village or town where the Bahnhof was located. To make this arrangement work for railway staff, posts had been "placed along the railway to mark out each minute of difference of time from Berlin," so that "enginedrivers and guards" could alter "their watches one minute for every ten miles as they travel east or west." This was necessary because train conductors were obliged to ascertain the local time of every intermediate station, so they could keep in touch with the time of their customers. As far as Christie was concerned, the German practice constituted an oddity; he called it "the reductio ad absurdum of local time.",23

Even though he failed to distinguish between Germany's North and South, Christie's broader assessment is hard to fault. Most German railway experts and political commentators shared the English scientist's verdict. A report on Einheitszeit that appeared in the Preussische Mitteilungen in 1891 likewise portrayed Germany's public time culture as anachronistic. The use of two different times - Berlin time for the railways' internal operations, local time for the station clocks - had been a frequent cause of confusion. Not only did it pose a risk for the safety of railway staff and 
passengers alike; it also tempted the travelling public into arriving at the station either early or late, and the price, in each case, was a loss of time. ${ }^{24}$

The prevailing sentiment among German advocates of national time harmonization was optimism, however. Their mantra was that the railways would bring Germany together in time. At least three assumptions tended to inform their thinking on this issue: that standard clock time, while just as real as local solar mean time, was better suited to the requirements of modern communication; that the forward march of history proceeded in the direction of increasing homogenization in most areas, including time; and, thirdly, that time reform would advance Germany's claim to being in the vanguard of universal progress. Among the contextual factors shaping the debate surrounding German time reform, two exerted particular weight: that much of the German South had known only one public time (namely, railway time) from the 1850s; and that, from about the 1870 s, standard time had become the subject of a global aspiration. Perceived through the prism of a linear philosophy of history, this twofold contrast (one with the southern German states, the other with the "civilized world") made for a worrying Gleichzeitigkeit des Ungleichzeitigen. Many reformers frankly acknowledged that only a minority of Germans used the railways regularly before 1900 . But then, as far as they were concerned, this was precisely what had to change: By problematizing the lack of Einheitszeit, they sought to create the modernity to which they aspired to belong.

When in 1872 Berlin time became Prussian railway time, the reform-minded public saw this as a sign that things were moving in the right direction. Many hoped that the extension of Berlin time to the rest of Germany would swiftly follow, marking another victory in the battle against localism and German particularism. ${ }^{25}$ For the 
German Verein für Eisenbahnkunde, standard time needed to move from the timetabling officials to the exterior of the railway station. In view of the advantages this would offer to passenger safety and convenience, this was a change they considered all but inevitable. It was in this spirit that in 1889 the association's delegates advocated the introduction of a standard time set to the Greenwich meridian, citing England, Sweden, the USA and Japan as countries where the reform had been carried out "with ease.,"26 Just a few years previously, a German railway expert had made a claim that would become a stock-in-trade among supporters of time reform: If "one night all of Germany's clocks, including pocket watches, were to be set to Berlin time" by an invisible hand, nobody would notice it the next day. ${ }^{27}$ In letters and articles to local and regional newspapers, contemporaries associated local time with "an anachronistic habit." Some insisted that the era when time was controlled by a few local notables had passed. Whoever called Einheitszeit "unnatural," one correspondent to a national newspaper grumbled, should also "desist from taking the night train or using electric light." To be truly consistent, he chaffed, they ought "to go to bed with the chickens" and get up with the cows. ${ }^{28}$ Meanwhile, in an 1891 letter to Reichskanzler von Caprivi, the German Architekten- und Ingenieur-Verein endorsed the introduction of a national time standard for the whole of public life. Its delegates dismissed the argument, made by defenders of local time, that a sizeable section of the German population was still sedentary. Instead, they claimed that railway time would help engender levels of mobility on a par with England. ${ }^{29}$

Calls that justified time reform with a felt need to modernize were not confined to influential personalities and pressure groups. As the case of Oberlehrer Hoff shows, much of the agitation derived from within civil society. In a talk he delivered to the 
Industrieverein Altona in 1891, Hoff began with the concession that, on grounds of habit, most people preferred local to standard time. He then enlightened his audience that the world was currently being divided into different time zones. Given that the much larger United States of America had recently adopted such a system, there was every reason to assume that Germany would follow suit. The structuring of the entire globe into time zones centered on G.M.T. Hoff described as "one more bond uniting civilized humanity in its efforts for cultural improvement." ${ }^{30}$ And when, in 1891 Baden, Württemberg and Bavaria declared their intention to adopt MEZ für das bürgerliche Leben, the Munich-based Allgemeine Zeitung demanded that Prussia follow suit. The difference between the time of Karlsruhe and the $15^{\text {th }}$ meridian (passing through Görlitz) was twenty-six minutes and nineteen seconds. For the editors, this nullified the argument that standard time was unfeasible in Prussia: No town in northern Germany, whether in the extreme west or east, would have to move its clocks by a substantially larger margin than would Karlsruhe from 1 April $1892 .^{31}$

Yet if reformist discourse of time contained a weakness, it was its onedimensionality. Justified for the most part in functional terms, time harmonization was difficult to sell in a society whose majority rarely travelled by rail (while a small minority travelled almost daily). ${ }^{32}$ More importantly: While reformers largely ignored the question of time's relation to place, in practice time acquired much of its social and emotive force through a process of relocation. ${ }^{33}$ A particularly potent way to accomplish this relocation of abstract time was nationalism. While industrial capitalism relied on "homogenous, empty time,",34 nationalism served to situate time within the national community. ${ }^{35}$ As mentioned at the start of this essay, the most salient effort to nationalize time along such lines was undertaken by Helmuth v. Moltke. Hailed 
retrospectively as the father of German standard time, Moltke relocated time in a nationalist key. On 16 March 1891, in his last speech to the Reichstag, the 91-year-old described the German status quo as a military liability and an obstacle to national progress:

Meine Herren, ... I will not long detain you, as I am very hoarse, on which account I have to ask your indulgence. That Einheitszeit is indispensable for the satisfactory operating of railways is universally recognized, and is not disputed. But, meine Herren, we have in Germany five different units of time. In north Germany, including Saxony, we reckon by Berlin time; in Bavaria, by that of Munich; in Württemberg, by that of Stuttgart; in Baden, by that of Karlsruhe; and in the Rhine Palatinate, by that of Ludwigshafen. We have thus in Germany five time zones, with all the drawbacks and disadvantages which result. These we have in our own fatherland, on top of those we encounter at the French and Russian borders. This is, I may say, a ruin which has remained standing out of the once splintered condition of Germany; but since we have become an empire, it is only right and proper that it should be done away with. ${ }^{36}$

The revered nonagenarian called Germany "our own fatherland," attributing the absence of a national time standard to Germany's former divisions: what he called the "once splintered condition of Germany." Like other prominent figures inclined to approach both past and present philosophically, the German war hero diagnosed a nagging Gleichzeitigkeit des Ungleichzeitigen. And as happens to be the case with practicing Hegelians, this was not meant to signal sympathy for those deemed ungleichzeitig. Moltke's state-reinforcing nationalism built on the contrast between an anachronistic 
present and a desirable future: in order to be strong and powerful, nations had to become tightly integrated states, and a single time standard seemed indispensable to attaining that ambition.

This argument became even more common once the adoption of MEZ began to look like a foregone conclusion. When in 1892 and 1893 regional and municipal authorities all over Germany began to dispatch their instructions on how to adjust public clocks to the new standard, the discordant voices receded. As when the Altonaer Nachrichten informed its readers that at midnight of 31 March 1893 the minute hands of the town's main clocks would be moved forward by twenty minutes. At that point, local time would "be erased in a single stroke" to make way for the brave new world of coordinated time across the nation. There was no doubt, the paper noted, that this would mean "a profound interference in established habits and customs." Yet the world of standardized time, so the editors continued, would come with a series of novel and largely unexpected charms, some of which were likely to warm a citizen's heart and soul. On New Year's Eve, for example, when all clocks would be in complete agreement, the whole of Germany ("Alldeutschland") would shout their festive greetings at the stroke of midnight: "For the glowing patriot, this commonality in festive spirit is very pleasant to say the least." ${ }^{, 37}$

The nationalist relocation of decontextualized time notwithstanding, the champions of national standard time faced strong opposition, particularly in Prussia. The outstanding opponent of the time reform proposed by Moltke was Chancellor Leo v. Caprivi. Another decorated war hero, Caprivi questioned Moltke's claim that Einheitszeit was decisive for Germany's war efforts, or that without it, people's lives 
would be at risk. As he wrote to minister v. Maybach, head of the imperial railways and an outspoken supporter of national standard time: "We do not wage a war every day, which is why we must ... refrain from citing the eventuality of a war to justify altering the living conditions of our population's lives in times of peace. ${ }^{, 38}$ On several occasions, Caprivi professed that "the large majority" of Prussia's population regarded the prospect of a national time (bürgerliche Einheitszeit) as "a troublesome burden," as something that "contradicted natural dispositions" (ein den natürlichen Verhältnissen widerstrebender, lästiger Druck). Caprivi's deputy agreed, noting that "large sections of the population" were "opposed to the introduction of a single time standard for the Empire as a whole." 39 The experience with the introduction of the metric system in weights and measures had shown that "the public" was "highly conservative" in matters affecting deeply engrained habits. ${ }^{40}$ Intent on depoliticizing the reform, Caprivi asked that the railway authorities (rather than the imperial government) take the lead. If the government forged ahead, the public would likely perceive the change as a "violent interference in established ways of life" (gewaltsamer Eingriff in eingebürgerte Lebensgewohnheiten). ${ }^{41}$

Of the Prussian state ministries, those concerned with finance and with internal affairs, as well as the ministries of war and of justice supported far-reaching time reform. Most doggedly opposed was the Ministry of Agriculture, whose speaker let it be known that many Prussians regarded the planned reform as a "severe interference with the law of solar time." Also against the introduction of standard time (except for the railways' internal operations) was the ministry responsible for religion, education and health. ${ }^{42}$ Unless people had been enlightened about the "deviation of railway time from the time regulating civil life..., total chaos in matters of public timekeeping" would 
likely ensue. ${ }^{43}$ Of Prussia's various chambers of commerce and trade (Handels- und Gewerbekammern), those of Kiel, Mühlheim am Rhein, Breslau, Liegnitz, Magdeburg and Schleswig were in favour of introducing MEZ for both the railways and public life; Königsberg, Erfurt, Brandenburg, Mehresburg were against. The three chambers of commerce (Handelskammern) and the "large majority of the local branches of the Landwirtschaftlichen Verein" were opposed. ${ }^{44}$

As well as widespread, skepticism toward time reform was multi-faceted. In 1884, a Berlin commercial newspaper concluded that time harmonization would mostly benefit the railways and their staff. The situation in southern Germany, where standard time had been adopted down to the level of the localities, was less congenial than some people had claimed: "The railway officials relieve themselves of the duty of converting times, but the travelling public has to cope with a different time every time it crosses a border." $"$ Two of Germany's most eminent astronomers, Wilhelm Foerster and Johann Gottfried Galle, warned against applying standard time except for the railway's internal operations. Foerster argued that plans to introduce what he described as "a homogenous time, one that is entirely unrelated to differences and changes of location," constituted “an imposition."46

Foerster's colleague, Johann Gottfried Galle, averred that not everything hailing from the US or England was worthy of emulation. Like Foerster, Galle stressed that his own discipline, astronomy, relied on local time, as did botany and agriculture. His advice to railway companies and state officials was unambiguous: "Which standard time the railways and telegraph agencies regard as useful to perform their operations is their own private business, which is of no concern to the public. ${ }^{, 47}$ As far as the two 
eminent astronomers were concerned, the stationary part of the population should not have to change its habits so that the minority of frequent travelers could be relieved of the inconvenience of living with different times. Endorsing Galle's views, the Hamburger Nachrichten maintained that, for many contemporaries, local time spoke to their "desire for peace and quiet" in a time characterized by "novelties and change." They also agreed with Galle that it was the railways, rather than the public, that had to cope with the temporal dislocation they had produced.

\section{Adjusting Clocks}

Talking clocks was important, but real clocks needed regular adjustment. Not that efforts to regulate mechanical clocks were an invention of the railway age. The German medievalist Gerhard Dohrn-van Rossum associates clock coordination with the "modernization and compression of temporal regulations." Driven by a quest for temporal consistency, such efforts have been made since the late-medieval period, particularly in towns. ${ }^{48}$ At the very end of his Geschichte der Zeit, which focuses on the medieval and early-modern periods, Dohrn-van Rossum devotes three pages to railway time. By the 1830s, he concludes, the "time of transportation" (Zeit des Verkehrs) had "made obsolete" the "time of the town" (Zeit der Städte). What he holds responsible for this transformation are three institutions of long-distance communication: the postal service, the timetabled coach service, and, finally, the railways. ${ }^{49}$

Yet such relegation of town clocks to time's secondary infrastructure proves unduly restrictive. It ignores the fact that time cultures were the product of both institutional pressures and context-specific agency; and that clocks, not despite but because they functioned as time tellers, had to respond to emotive and identificatory 
needs. ${ }^{50}$ The view of the hegemony of time of transportation (of any time, really) ignores that many felt (and still feel) compelled to make their own time.

The material quality of clocks, their role as objects of status, tradition and sentiment, is crucial to this story. "Human beings," Leora Auslaender has noted, "need things to individuate, differentiate and identify; they need things to situate themselves in space and time." ${ }^{, 51}$ In a fascinating chapter on the assimilation of clocks in the American Republic, Thomas M. Allen has offered the following perspective: "A clock might embody a variety of ideas about time held by the clock maker, cabinet maker, and patiner who worked on the object. When brought into someone's home, the clock puts these ideas into circulation with the preexisting versions of temporality already present in the household. Thus, the clock is both a representation of existing beliefs and a source of new ideas about time. ${ }^{, 52}$ The ideas that railway time put into circulation as it entered a German village or town may have been less variegated than those embodied by the clocks placed in US-American households. But the essential dynamic - different ideas and objects of time seeking some kind of accommodation - is eminently comparable. $^{53}$

Sometimes public time pieces differing from each other by a few minutes was all it took for people to call a state of temporal anarchy. This was the case in Augsburg, where in 1836 some clocks displayed local solar time while others had switched to local solar mean time. The resulting divergence prompted the Augsburger Tagblatt to enlighten its readers about the difference between the two notations. ${ }^{54}$ Half a decade later, the editors of the Allgemeiner Anzeiger und Nationalzeitung der Deutschen pointed to the pitfalls of common practice of setting village clocks to the time tellers of a larger town. ${ }^{55}$ The main problem with this approach was that "many town clocks were 
just as wrong as those in the village." ${ }^{, 56}$ In the same year, a Munich daily likewise attributed the faulty time told by the clocks of Starnberg, Andecks and Seefeld to the three municipalities putting their trust in Munich's church clocks, which were notorious for their erratic movements. ${ }^{57}$ Meanwhile, the Augsburger Tagblatt devoted a frontpage editorial to what it described as the town's temporal confusion. It had long been apparent, so its author lamented, that the inhabitants of Augsburg were not exactly spoiled with reliable time pieces. Yet a short walk along some of its landmarks had revealed that the situation was even worse than he had assumed, with four of the city's church clocks ringing the hour a full fifteen minutes apart. While variations in temperature frequently affected the accuracy of church clocks, their consistency could be improved through a regular regime of adjustment and maintenance. What is revealing is the author's prioritisation. While he criticised the inaccuracy of individual clocks, what he deemed most unacceptable was their lack of agreement: There were now "many people from different walks of life" who had a vested interest in not getting their temporal signals crossed. ${ }^{58}$

When Munich time became the state's railway time in 1854, Augsburg's station clock moved to the centre of public attention. ${ }^{59}$ To alleviate the potential for temporal discordance between station and town, a discussion began about installing a new master clock near the Cathedral, one of its dials facing the public. But Augsburg in the second half of the nineteenth century was no small town. While a new master clock near the town centre made life easier for some, it was of little consequence to the majority who lived in neighbourhoods further afield. Out of habit and because of its elevated position near the town centre, most inhabitants took their cue from the Perlach clock. With roots stretching back to the ninth century, the Perlach clock tower underwent a massive 
extension when the new town hall was built between 1612 and 1618. Because it adjoined the town hall and market square, and also due to its height of 64 metres, the Perlach clock had long served as Augsburg's unofficial master clock. ${ }^{60}$

Yet being a mechanical clock requiring regular adjustment, Perlach was prone to defects and irregularities. Between the 1850s and 1870s, it found itself engaged in a struggle for hegemony with the station clock. In June 1856, some observed that Perlach was lagging about fifteen minutes behind the station clock. ${ }^{61}$ Subsiding for short periods at a time, the problem would invariably recur, and so the debates over temporal consistency continued. ${ }^{62}$ In 1860 , an inhabitant asked that a new master clock, synchronised with the station clock, be installed near the Cathedral. Augsburg, he asserted, deserved at least one accurate timepiece near the centre of town, all the more so as the Perlach tower clock had become unreliable. ${ }^{63}$ Since most inner-town clocks emulated Perlach's movements, the erstwhile master clock had become a source of contagion. ${ }^{64}$ In 1862 a citizen demanded that the former rule, that Perlach had to be set daily to the station clock, be reinstated; or else the city was in urgent need of a new master clock, to be fitted near the town hall. Another citizen maintained that the problem lay not with Perlach but with the station clock having been inaccurate of late, a claim that was subsequently confirmed by Ober-Inspektor Lauboeck. ${ }^{65}$ When a Reutlingen-based company visited Augsburg in 1867 to assess its horological needs, it recommended the fitting of an electrical master clock capable of driving the movements of 20 clocks that were to be distributed across the city. ${ }^{66}$

As the Augsburg example shows: the search for a visible clock, one that could command authority, began well before the German railways emerged as a means of 
mass conveyance in the late nineteenth century. Normaluhr is the term most German contemporaries used to describe a clock that served as an authoritative referent for other timepieces (the British and Americans called it master clock). Some were newly fitted, yet most were well-established; many had a long history and needed an upgrade. In places of work or entertainment, in courts of law or city neighbourhoods, such reference clocks began to draw the attention not only of officials and experts. Which clock is to serve as the Normaluhr? Quite often the question elicited conflicting answers, reflecting disagreements over reference times or the quality of existing clocks. In Ansbach, for instance, the local astronomer accused the town's clock regulator, Mr Schlemmer, of setting popular clocks to solar time instead of local mean time as the new convention demanded. Schlemmer was said to obtain his time from the postal conductors, who had a reputation for their faith in solar time. ${ }^{67}$ While in all parts of Germany municipalities were asked to substitute local mean for solar time, both times continued to coexist in some places, at least for a while. As late as 1848 , the clockmaker Joseph Schechtl advertised his "clock towers that display both mean and true time." ${ }^{, 68}$ What Schechtl called true time was the prevalent term for solar time.

As telegraph-supported railway communication heightened from the $1860 \mathrm{~s}$, questions surrounding the accuracy and coordination of time moved centre stage. Even at that point, however, bringing clocks into agreement posed numerous challenges. Much "valuable time" was still "being wasted," a contemporary lamented in 1865, "because divergent clocks caused people to be either early or late." This made him wonder why, in Germany of all countries, so few electrical master clocks could be found. While such clocks graced the temporal landscapes of London, Liverpool and Glasgow, as well as of Paris, Lyon, Mulhouse, Brussels and even Ghent, in Germany 
there had been much talk and little action. ${ }^{69}$ The contemporary in question was not alone in his distrust of mechanical clocks and of the watchmakers who continued to advertise them. "What time is it?," an inhabitant of Amberg in the Upper Palatinate asked in a letter printed in a local newspaper. His answer: 'I do not know, because I'm not supposed to prefer my own watch over the public clocks that regulate our business affairs. But these public clocks have long been a source of misery." While the parish church clock was "either fast or slow" or inaudible, the school clock suffered from those very same deficiencies - if it didn't "stop moving altogether," that is. The station clock, besides proving inconsistent of late, was rather a long way from the town centre: "Are we supposed to walk to the railway station each time we desire to obtain the correct time, and then measure the time it takes us to get back home?"70

This disgruntled owner of a pocket watch raises two points that warrant a little further probing. The first pertains to the difference in authority between pocket watch and public clock. Something appears to have changed in this regard, at the time when he was making his observations. As historians of a recent investigation into time and public clocks in Frankfurt have argued, it would have made little sense to mass-produce pocket watches of great precision before 1800 . The clocks that mattered, socially and economically speaking, were a select number of town clocks. Few people could afford a precise watch of the sort carried by railway staff or affluent citizens. ${ }^{71}$ With the arrival of the railways, the established hierarchy between public and private timekeeping appears to have been challenged somewhat. Not that a pocket watch suddenly counted for more than a public clock. Who could really tell if someone's watch was trustworthy, anyway! But with the spread of railway time, people could cite a private watch as a witness if they wanted to challenge the authority of a public clock. If more than a 
handful of individuals did so, those entrusted with public timekeeping needed, at the very least, to acknowledge the problem; and if the complaints persisted, they had to fix it, either themselves or by entrusting the required repair to a recognised expert. ${ }^{72}$

The question concerning the hierarchy of private and public timekeepers is closely allied to the second issue raised by the contemporary, one that would deserve much greater scrutiny from historians with an interest in the cultural and social history of time. ${ }^{73}$ The issue concerns railway time's nearest embodiment: the station clock, its status and significance. One reason why people carrying pocket watches could now challenge the authority of a public clock was that the number of clocks displaying railway time had increased substantially. Set daily by telegraphic time signal or a chronometer-carrying train conductor, station clocks in particular emerged as objects of authority. While we are lacking exact (indeed any) figures on the distribution of railway station clocks in Germany, it is clear that the number of such clocks must have increased in line with the extension of the network. Yet as Siegfried Weichlein has shown for the German railways, the extension of this important means of communication was patchy in a way that heightened (rather than reduced) social disparities, at least initially. In Weichlein's evocative phrase: railway paradises existed alongside railway deserts. ${ }^{74}$ To risk a broad yet plausible generalization: Before the 1880s the railway-clock paradises were more likely to be found in cities and towns than on the countryside. ${ }^{75}$

Returning to our clock watchers: Even those who regarded station clocks as pathetic symbols of officialdom found it hard to ignore them. Many quickly accepted the station clock as the new reference clock. Returning to the example of the individual 
wearing a pocket watch: What had changed was less the precision of the average pocket watch (the movements of most pocket watches were predictably erratic and required daily adjusting); what had changed was that now someone carrying a watch could gain credibility by synchronising it with a railway clock. It was for this very reason that railway clocks could undermine the status of more established clocks. But this did not result, as Dohrn-van Rossum has suggested in his monumental history of time, in town clocks' relegation to urban folklore, picturesque yet functionally redundant.

One reason why neither town nor village clocks declined in importance has been mentioned already: the train station was often located at least ten minutes from the town or village it was supposed to serve; and even where the station clock was located nearer the town centre, it may well have been invisible to a large portion of the inhabitants. Many small and rural stations featured a single clock fitted along the platform but none to the exterior. There were even some larger stations that left people in doubt about the correct time of day as they approached the station. The Sternschanzenbahnhof in Hamburg, for example, did not feature a single external clock visible to the public before receiving a major overhaul in $1903 .^{76}$ But all this became less acceptable once railways had begun to run on standard time.

What drew many people to the station clock was thus not that it was flawless but that it became the bearer of Einheitszeit. It is worth repeating that from the mid 1850s, towns and villages in the German South were encouraged to adopt the time of either Munich, Stuttgart, Karlsruhe or Ludwigshafen; but there was no obligation to do so (the legal basis for such a demand was lacking). A district such as Bayreuth, which decided to introduce Munich time just a fortnight after it had become the standard time in 
Bavaria, was the exception. Numerous districts and municipalities took at least a decade until they synchronised their local clocks with railway time, and many took considerably longer. ${ }^{77}$ It was not until 1873 , for example, that the busy commercial towns of Kempten and Fürth set their local clocks to Munich time. ${ }^{78}$ Yet, once a regional standard time was introduced (even where local times remained initially in place) this invariably boosted the authority of the station clock.

Of the examples supporting this claim, none may be more compelling than inhabitants and municipalities putting local clocks forward by ten or more minutes to ensure that people would get to the railway station in time. Clock manipulations of this kind could become near-habitual, at least for a while, under certain conditions. ${ }^{79}$ If the railway-travelling portion of the population was sizeable, and if the station was a good walk away from the centre of a town or village, the temptation to turn minute hands forward was considerable. These conditions appear to have been present in Bamberg. Ten years after the Bavarian authorities had installed Munich time as the time for the railways' internal and external operations, Bamberg decided to substitute railway time for local time. Bamberg was lucky insofar as the city's clocks had to be advanced by a mere three minutes. When it came, the time switch prompted mixed reactions, but no active resistance. As a local newspaper judged the move: with the railways now dominating "business transactions" also in Bamberg, the adaptation had become all but inevitable. What it did not condone was something else: that the minute hands on some of Bamberg's public clocks had been advanced by "another $6-8$ minutes." What had prompted this was a "concern for the travelling public." While this concern was understandable, the report's author noted, the action taken suggested that the manipulators suffered from a delusion: trains were being missed by people running late, 
not by clocks displaying a particular time; whether or not those clocks were set to local or railway time was irrelevant. Besides, putting the clocks forward by six to eight minutes was a "completely futile" exercise. Since it took about fifteen minutes to get to the railway station from the town centre, clocks would need to be adjusted by at least a quarter of an hour for the manipulation to fulfil its intended purpose. ${ }^{80}$

Above all, however, the selective fast-forwarding of a limited number of clocks left Bamberg in a state of temporal confusion. Those carrying out a trade, or children walking to their school, were left uncertain as to the correct time of day. This unpleasant state of affairs could only be overcome, the report suggested, by turning the town hall clock into the city's official master clock. To this end, the town clock maker would need to obtain Munich or railway time every morning at 7 a.m. from the Telegraph station. And at 8 a.m., all church clocks would have to be synchronised with the town hall clock. Once the public could be certain that all public clocks showed railway time, they were free to set their house clocks back by three minutes so that they would display the local mean time of Bamberg. Aside from the advantages of synchronicity and predictability, the proposed strategy would offer another benefit. Here the author referred to that most extraordinary event, the birth of a child: "Someone who wants to register the age of his new-born child, born when the town hall stroke 12 noon, would, in case he wished to register his child's birth by Bamberg local time, have to state the time as 11 hours and 57 minutes."

How does the North of Germany, whose population was shielded from adjusting local clocks to railway time until 1893 , fit into this picture? As far as temporal accuracy and precision was concerned, there is no reason to assume that the problems were 
fundamentally different from the South: Village and (particularly) town people in Prussia defended familiar clocks, complained about temporal disharmony where they found it, blamed local regulators when clocks got out of sync, or, more generally, advanced conflicting accounts of why they thought a local time culture was less than satisfactory. Which clock was to be regarded as authoritative? Many institutions had to find an answer to this simple question. This was relatively straightforward in the case of the starting time of rehearsals and plays for Berlin's actors; they had to follow the chief timepiece of the theatre where they worked (which was obliged to follow the clock of the Berlin Academy). ${ }^{82}$ It was more difficult in less regulated local settings, where different vested interests and sensibilities could undermine any hope of a swift compromise.

Yet the main initial difference to the South - the absence of a standard time that could have regulated everyday life - could still prove consequential. In this respect, courts of law provide a particularly instructive example. In response to the diversity of legitimate times and temporal referents, courts in Prussia often took a strikingly pragmatic approach. Many showed considerable leniency, for example, towards witnesses or plaintiffs arriving late from nearby towns and villages. When a group of rural folks turned up "just a few minutes late" to the court in Mühlhausen in Thuringia, they were given the benefit of the doubt. For not only did their village clocks differ from Mühlhausen's town hall clock by a few minutes; but the latter had also a reputation for being fast. ${ }^{83}$ The correct timing of witness statements could decide over whether someone had to go to prison, or worse. This became evident in 1849 , when a group of nine witnesses saw themselves subjected to the charge of perjury in the Wrietzen district court in Brandenburg. What saved them from a lengthy prison term 
was the revelation that they had obtained their time from a peculiar Normaluhr, one that had made them believe in a truth (namely, that a notorious thief had an alibi for the time a burglary was committed in Strausberg) that turned out to be fake. The legal periodical reporting the case resorted to sarcastic wit to justify why leniency had prevailed: Each witness had portrayed the external world not as it really was, but rather in the way in which he or she had "absorbed it" — a little like "Dr. Luther when he proclaimed to have seen the devil on the Wartburg without the latter having been present in the flesh." 84

As late as 1890, Prussian experts on civil court proceedings defended the priority of local over railway (then Berlin) time in legal proceedings. In the absence of a legally binding time referent, what counted to them was the time that "found common recognition by virtue of established habit and long practice in the common life of a particular location." What was decisive was the "chime of the clock" which the inhabitants of a municipality regarded as "the important one." 85 Not everyone who attended a court hearing would "travel by railway," the report added. Besides, those living in the town where the court was located, particularly judges, often had "no secure knowledge of the time displayed on the station clock." ${ }^{, 86}$ A similar practice appears to have prevailed in the Grand Duchy of Mecklenburg-Schwerin in the 1880s. Its state law decreed that what defined legal time was neither "astronomical time" nor "the tower clock" but rather "that particular clock towards which public life is generally orientated. ${ }^{, 87}$ What we see here, in other words - fifteen years after Berlin time was adopted as Prussia's railway time and six years before MEZ was adopted as Germany's time standard - is a Gewohnheitsrecht, a practice defined by prevalent popular custom. In a public culture that restricted Eisenbahnzeit to the railways innerer Betrieb up until 
1893, notables and civil servants appear to have had no qualms standing up for local time.

Yet the picture is far from clear-cut. What determined the temporal pragmatism that informed legal proceedings was the complexity of a law court's operations. What mattered most was the fact that staff, defendants, plaintiffs and witnesses travelled to the court from different locations, and hence observed different times. In other areas of activity, however, and particularly in towns and cities, the approach to time appears to have been more formalised and rigid. Several factors may have contributed to this tendency, including public transport, where the champions of local time came under increasing pressure. Tramway traffic in Hamburg offers a case in point. As early as 1866, the regulations of the horse-drawn tramway between Hamburg and Wansbeck linked departure times to the station clock, which was set to the postal clock that doubled as the city's master clock. In 1875 , the clock that regulated the departure times of tramways was still the station clock; in1887, it was the clock by the stock exchange; and in 1895 , by which time the tramway had gone electric, the station clock had resumed the role of local master clock. ${ }^{88}$ Meanwhile, in Mainz in the 1880 s tramway conductors had to carry a "pocket watch set to the station clock." ${ }^{89}$ In Weimar in 1910 , those working on the city’s tramway had to carry “an accurate pocket watch synchronised with the station clock," whereas the hackney cab drivers had to set theirs to the "town hall clock." At that point both the station and town hall clocks followed M.E.Z., but what now determined the choice of master clock was visibility, which of course depended on the route. ${ }^{90}$

In some of the larger Prussian cities, too, the synchronisation of clocks had long 
presented a major concern. When in 1889 the Berliner Börsenzeitung offered a report of Berlin's newest hotels, it attributed their popularity with the travelling public to their location in striking distance of railway clocks. There at last, busy individuals would not see their time wasted as a result of temporal contradiction. As the report described the charms of the recently opened Hotel Monopol opposite Stadtbahnhof Friedrichstrasse: "Sitting comfortably at the window and his eyes gazing at the station clock, the traveller is able to expect the arrivals and departures of the trains, almost to the minute, in a state of thorough relaxation."91 Evidently excited, the editors judged that, "Very soon the passenger who, distrustful of all watches including his own, would enter the waiting room a good hour before the departure of his train, where, haunted by suffocating boredom, he would sit anxiously until he heard the 'third ringing' of the bell, followed by the station guard's shouts of 'all aboard! - very soon this passenger will appear like the mythical figure from a distant past." ${ }^{92}$ Progress, for the Börsenzeitung, meant conquering boredom and time-wasting by stamping out temporal ambiguity.

The impending introduction of railway time for both the internal and external operations reinforced tendencies and dynamics already at play. In particular, it heightened the visibility and boosted the authority of the station clock also in the German North. In 1891, minister von Thielen asked Prussia's railway directorates for reports on the situation concerning visible clocks on their part of the network. The directorate in Elberfeld replied that it had ordered "more than 100 station clocks, to be fitted above all at the exterior of stations and in waiting rooms" at the cost of 10,000 Mark. ${ }^{93}$ Its counterpart in Breslau informed the Ministry of its purchase of " 29 platform clocks", "25 clocks ticket-office clocks" and "three regulators" at a total cost of approximately 12,000 Mark. ${ }^{94}$ Meanwhile, the railway directorate in Berlin replied that, 
"with the exception of Berlin-Stralsund", the "the large majority of the district's stations on secondary lines" had been fitted with station clocks that were "visible from outside". "Eight stopping points on main lines" and "eleven stations on secondary lines" still needed to be "fitted with a station clock". 95

More clocks meant greater attention to their accuracy and coordination. In 1898, for instance, an investigation of the accuracy of the clocks of dozens of train stations in Prussia drew a thoroughly positive conclusion. Although the inspected clocks had not in each instance proved entirely accurate or in perfect agreement, the deviations had been rather small: "barely half a second". 96 The accuracy and coordination of clocks improved in many a railway station, as did their visibility. In 1903 the three clocks at Hamburg's Schanzenbahnhof - one of which was situated along the platform, another near the ticket counter, and the third inside the main building - were complemented by a fourth. The latter was fitted to the station's busy side entrance on Schanzenstrasse. All four clocks were synchronised by electric impulse. ${ }^{97}$

Much suggests that during the 1890 s controversies over clocks that were either irregular, out-of-sync or invisible had become sharper, with tolerance levels in case of temporal divergence having further decreased. In 1898, when the church clock of a Prussian Gemeinde differed by "between ten and twenty minutes" from the station clock, the local police authorities were asked to have a word with the cleric in charge. ${ }^{98}$ A decade later, several inhabitants of Elmshorn in Schleswig-Holstein demanded that the existing station clock be fitted to a more congenial location, one which enabled them to see it on approaching the station. ${ }^{99}$ When in 1910 the Roman numerals adorning Berlin's town hall clock were replaced by Arabic ones, the city's commercial community welcomed the alteration. Along with this endorsement came the suggestion 
that henceforth Arabic numerals be adopted as standards on all public clocks in Berlin, including church clocks. ${ }^{100}$

All things considered, then, time is a subject that will leave the lumpers among the historians slightly less satisfied than the splitters. That is because most large-scale generalisations on time cultures tell us more about rules and intentions, important though they were, than about how members of particular communities related to (and made use of their) time.

The previous examination thus suggests that Gustav Schmoller was right to err on the side of caution. The German railways did push time coordination to new levels beyond locality, regional state and towards and beyond the nation. They had the potential to create a single national clock, and, in some ways, they did. Yet they only attained this on a purely formal and institutional level. Socially and culturally speaking, time cannot be formalized in this way, however vigorous its technological underpinnings. Standard time, when and where it was adopted, did not produce a single culture of time. The vision of the one-clock-fits-all, that dream of both nationalist and cosmopolitan champions of standard time, never penetrated very deep into the fabric of social life. Yet what may be more surprising is something else: that it was the railways - that alleged incarnation of linearity, that machine that Wolfgang Schivelbusch described as the "destroyer of experiential space and time" - which (however indirectly) enabled contemporaries to reembed mechanical clock time. The railways helped them to relocate a time that was supposed to dethrone local parochialism in all its various incarnations.

In the absence of railways, clock time would not have become so ubiquitous so 
fast in the nineteenth century - neither in Germany nor elsewhere. Yet as this essay has demonstrated drawing on a variety of examples, clock time goes much deeper than standard time. Out of curiosity and because their lives depended on it, Germans took an interest in obtaining the right time from the frequently contradictory horological landscapes they inhabited. The inspectors of the station clocks who showed a professional obsession with accuracy and synchronicity; the townsfolk in southern Germany who fast-forwarded their favorite public clocks with the best of intentions; the Prussian notables, scientists and villagers who opposed railway time becoming public time - they all, in their own way, contributed to putting time back in its place. What this suggests is that decontextualized clock time may have been most disconcerting for the many who barely ever boarded a train. To those who embarked on railway journeys frequently, or who had access to a railway station, it may have lost its abstract quality after a relatively brief period of acclimatization.

Another reason why the nineteenth-century railways may have strengthened local identity concerns the materiality of clock time. In this respect, the station clock appears to have assumed a kaleidoscopic function. The station clock gave abstract time a place. Even though the standard time it displayed bore no relation to a specific location, the clock's materiality (its emotive tangibility?) affixed time to a local context. The station clock was neither abstract nor specific: it could be both. Nor was it a passive device. As station clocks gained in significance, they contributed to initiating new patterns of learning, imparting new habits, new ways of seeing and moving that with time became part of people's everyday routine. Of course, the extent to which a station clock could sustain a sense of community depended on a number of factors, including its visibility, position, aesthetic qualities, a person's relationship to the railways, the 
frequency with which they travelled; and perhaps even someone's history with and attachment to a place, what we might call their local patriotism. Depending on all these factors and their interplay, station clocks may have proved more or less effective as kaleidoscopes of modern times. At its best, the station clock may have succeeded in reconciling, on a cognitive and emotional level, empty homogenous time with established temporal landscapes. The result, in each case, was something new; but also, something that, in spite of its novelty, looked eerily familiar.

\section{Notes}


* I wish to thank the organisers and participants of the Central European History Seminar at Vanderbilt University (especially Celia Applegate, David Blackbourn and Helmut Walser Smith) for giving me an opportunity to present ideas informing this essay in Nashville in September 2018. The insightful suggestions by the two anonymous reviewers for CEH proved invaluable, as did the feedback I received from Jim Brophy, Jean-Michel Johnston, and Tobias Straumann. The research for this article benefitted from the award of a Major Research Fellowship by The Leverhulme Trust (Project Grant: MRF-2014-036).

${ }^{1}$ Gustav Schmoller, "Über den Einfluss der heutigen Verkehrsmittel," Preussische Jahrbücher 31 (1873): 424.

${ }^{2}$ The literature on railway time is large. For two illuminating treatments of the nineteenth-century debate, see Wolfgang Schivelbusch, Geschichte der Eisenbahnreise. Zur Industrialisierung von Raum und Zeit im 19. Jahrhundert (Frankfurt am Main: Fischer, 2000 [1977]); Rebecca Solnit, “The Annihilation of Time and Space,” New England Review 24, no. 1 (Winter 2003): 5-19. For a contemporary accounts, see Leonard Waldo, „Railroad and Public Time,“ The North American Review 137, no. 325 (Dec 1883): 605-609; Otto Bähr, “Ortszeit, Weltzeit, Eisenbahnzeit, Zonenzeit,” Grenzboten 50 (1891): 433-447.

${ }^{3}$ „Gesetz nr. 2075, betreffend die Einführung der einheitlichen Zeitbestimmung, Reichsamt des Innern, March 16, 1893, Reichs-Gesetzblatt, no. 7, 93.

${ }^{4}$ In 1889, an imperial Denkschrift on standard time recommended that Germany emulate Prussia and Alsace-Lorraine, where Berlin time determined the operational side of the railways, with villages and towns operating on local time: one clock fits all, but 
only for the railways, and with Prussia imposing Berlin time on the rest of Germany. A copy of the memorial can be found in Hauptstaatsarchiv Stuttgart (HStAS), E 40/16 Bü 168.

${ }^{5}$ Atonaer Nachrichten, April 15, 1893. After 1872 Prussia's (and Saxony's) railways had run on Berlin time. On time coordination and standard time, see Peter Gallison, „Einstein's Clocks: The Place of Time,“ Critical Enquiry 26 (winter 2000): 355-89; Vanessa Ogle, The Global Transformation of Time 1870 - 1950 (Cambridge MA: Harvard University Press, 2015); Ian R. Bartky, One Time Fits All: The Campaign for Global Uniformity (Stanford: Stanford University Press, 2007). The symbolic and economic significance of Germany's railways preceded their capacity to generate a large travelling public. See Die Eisenbahn in Deutschland. Von den Anfängen bis zur Gegenwart, ed. Lothar Gall and Manfred Pohl (Munich: C. H. Beck, 1998), 9-19; Schivelbusch, Geschichte der Eisenbahnreise, ch. 3. There was no comparable time lag in England. On Britain, see Michael Robbins, The Railway Age (Manchester: Manchester University Press, 1962); Michael Freeman, Railways and the Victorian Imagination (New Haven and London: Yale University Press, 1999). For a global history of transport by a contemporary, see Michael Geistbeck, Der Weltverkehr. Seeschiffahrt und Eisenbahnen, Post und Telegraphie in ihrer Entwicklung dargestellt, 2nd edn., (Freiburg im Breisgau: Herdersche Verlagsbuchhandlung, 1895), 327-349. ${ }^{6}$ HStAS, M1/4Bü 330, Ministerium d. Innern an die K. Stadtdirektion Stuttgart und die K. Oberämter, March 1, 1892. See also HStAS, E 40/51, Bü 89, Verfügung des Ministeriums des Kirchen- und Schulwesens betr. Die Ordnung der Unterrichtszeit in den Volksschulen und den kleineren Gelehrten- und Realschulen infolge der Einführung der sogenannten mitteleuropäischen Einheitszeit, February 23, 1892. The reform and its 
intricacies filled the pages of major and provincial newspapers. See, for example, Altonaer Nachrichten, March 28, 1892

${ }^{7}$ HStAS M 40/51, Bü 89, Königl. Preuss. Gesandtschaft in Württemberg an Staatsrat Freiherr v. König, September 23,1892.

${ }^{8}$ Two factors in particular appear to have facilitated Britain's early adoption of a time standard underpinning both the railways and public life. One concerns its lead in communication density (industrialization and urbanization), the other its relatively modest east-west extension. The introduction of GMT-based zone times is discussed in Ogle, The Global Transformation, ch. 3, Bartky, One Time Fits All, ch. 8. On density of communication in comparative perspective, see Jerrold Seigel, Modernity and Bourgeois Life: Society, Politics, and Culture in England, France, and Germany since 1750 (Cambridge: Cambridge University Press, 2012), 31.

${ }^{9}$ That Germans who believed in "progress" liked to look to Britain above all other countries, and that their obsession was particularly manifest in relation to time and speed, cannot be seriously doubted. On this topic, see Oliver Zimmer, "Die Ungeduld mit der Zeit: Britische und deutsche Bahnreisende im Eisenbahnzeitalter, Historische Zeitschrift 308, no. 1 (February 2019): 46-80.

${ }^{10}$ James M. Brophy, "The End of the Economic Old Order: The Great Transition, 1750 - 1860," in Oxford Handbook of Modern German History, ed. Helmut W. Smith (Oxford: Oxford University Press, 2012), 169-194; G. Herrigel, Industrial Constructions: The Sources of German Industrial Power (Cambridge: Cambridge University Press, 1996). On the railroads' economic impact, see Rainer Fremdling, "Railroads and German Economic Growth: A Leading Sector Analysis with a Comparison to the Unites State and Great Britain," The Journal of Economic History 
37, no. 3 (1977): 583-604. On railways and national communication, see Abigail Green,

Fatherlands: State-Building and Nationhood in Nineteenth-Century Germany

(Cambridge: Cambridge University Press, 2001), ch. 6; Siegfried Weichlein, Nation und Region: Integrationsprozesse im Bismarckreich (Droste: Düsseldorf, 2004), 70-104.

${ }^{11}$ For important recent work, see inter alia: Thomas M. Allen, A Republic in Time:

Temporality and Social Imagination in Nineteenth-Century America (Chapel Hill, University of North Carolina Press, 2008); Mark M. Smith, Mastered by the Clock: Time, Slavery, and Freedom in the American South (Chapel Hill, 1997); Alexis McCrossen, Marking Modern Times: A History of Clocks, Watches, and Other Timekeepers in American Life (Chicago: Chicago University Press, 2013); On Barak, On Time: Technology and Temporality in Modern Egypt (Berkeley: University of California Press, 2013); Giordano Nanni, The Colonisation of Time: Ritual, Routine and Resistance in the British Empire (Manchester: Manchester University Press, 2012); Avner Wischnitzer, Reading Clocks, Alla Turca: Time and Society in the Late Ottoman Empire (Chicago: Chicago University Press, 2015); Ogle, The Global Transformation; Hannah Gay, "Clock Synchrony, Time Distribution and Electrical Timekeeping in Britain, 1880 - 1925,” Past \& Present 181 (2003): 107-140; Iwan Rhys Morus, “'The nervous system of Britain': space, time and the electric telegraph in the Victorian age," The British Journal for the History of Science 33 (2000): 455-475.

${ }^{12}$ Helmut v. Moltke, “Gesammelte Schriften und Denkwürdigkeiten,” Bd. 7, Reden des Generalfeldmarschalls Helmuth v. Moltke (Berlin: Mittler, 1892), 38-39.

For a useful recent summary of available knowledge, one that puts Germany in its international context, see Richard Evans, The Pursuit of Power: Europe 1815 - 1914 (London: Penguin, 2016), 389-396. See also Bartky, One Time Fits All, 122-126; Jürgen 
Osterhammel, Die Verwandlung der Welt. Eine Geschichte des 19. Jahrhunderts

(Munich: C. H. Beck, 2011), 118-126. The best treatment of time reform in Germany is Ogle, The Global Transformation, ch. 1. For an illuminating contemporary account, see Ernst von Hesse-Wartegg, Die Einheitszeit nach Stundenzonen (Dresden, 1892). The two classic syntheses, by Thomas Nipperdey and Hans-Ulrich Wehler, have nothing to say on the subject; nor do more recent syntheses of German history.

${ }^{13}$ Although their work on time was not centred on the modern nation-state, both E.P. Thompson and David Landes examined how clock time and time awareness manifested themselves in particular national contexts. While Landes focussed on technological innovation, Thompson attributed the rise of time discipline to capitalist modes of production. See E. P. Thompson, “Time, work-discipline and industrial capitalism,” Past \& Present 38 (1967): 56-97; David Landes, Revolution in Time: Clocks and the Making of the Modern World (Cambridge MA: Harvard University Press, 1983). Critics of these classic interpretations include Paul Glennie \& Nigel Thrift, Shaping the Day: A History of Timekeeping in England and Wales 1300 - 1800 (Oxford: Oxford University Press, 2009), ch. 2; Nanni, The Colonisation of Time; On Barak, On Time; Wischnitzer, Reading Clocks; Ogle, The Global Transformation. See also Stephen Kern, The Culture of Time and Space, 1880 - 1918 (Cambridge MA: Harvard University Press, 1983).

${ }^{14}$ Wolfgang Schivelbusch, "Railroad Space and Railroad Time," New German Critique 14 (Spring, 1978): 40.

${ }^{15}$ The tendency to view time in terms of multiple modernities is on full display in Glennie \& Thrift, Shaping the Day, 28. For a recent critique of the multiple modernity thesis, see James Vernon, Distant Strangers: How Britain Became Modern (Berkeley: University of California Press, 2015). 
${ }^{16}$ For accounts that explore time culture as a dialectic between time as formal referent and as social experience, see Mark M. Smith, "Old South in Comparative Perspective," American Historical Review 101 (December 1996): 1435; Alain Corbin, “The Daily Arithmetic of the Nineteenth Century," in idem., Time, Desire and Horror: Towards a History of the Senses (Cambridge: Polity, 1995), 1-12.

${ }^{17}$ The phrase that time was “nature's way to keep everything from happening all at once" is attributed to the US theoretical physicist Archibald Wheeler. Cited here in James Gleick, Time Travel: A History (London: $4^{\text {th }}$ Estate, 2016), 9.

${ }^{18}$ As Michael O’Malley put it: 'Standard time, like standard money, was a universal solvent dissolving the glue of local tradition and custom." See O’Malley, Keeping Watch: History of American Time (New York: Viking, 1990), 79-80.

${ }^{19}$ Focusing on processes of standardization and communication in nineteenth-century Britain, James Vermont speaks of a world of "distant strangers" that prompted "a reanimation of the local and the personal." Vernon, Distant Strangers, xi, 15. More explicitly focused on the construction of nationhood outside of Prussia, works exploring nineteenth-century modernity through a regional or local prism have long occupied a prominent place in German history. The two classic exemplars are Celia Applegate, $A$ Nation of Provincials: The German Idea of Heimat (Berkeley: University of California Press, 1990); Alon Confino, The Nation as a Local Metaphor: Württemberg, Imperial Germany, and National Memory, 1871 - 1918 (Chapel Hill: University of Carolina Press, 1997). For a discussion of this historiographical paradigm, see David Blackbourn and James Retallack, Localism, Landscape, and the Ambiguities of Place: Germanspeaking Central Europe, 1860 - 1930 (Toronto: Toronto University Press, 2007), esp. Introduction. The theme of time and social rhythms, which is peripheral to the older 
historiography on region and nation, is central to Oliver Zimmer, Remaking the Rhythms of Life: German Communities in the Age of the Nation-State (Oxford: Oxford University Press, 2019).

${ }^{20}$ The Times, March 22, 1886, 3.

${ }^{21}$ Ibid. See also the commentary by the Austrian geodesist Robert Schram, "The Actual State of the Standard Time Question," The Observatory 161 (April 1890): 139-146.

${ }^{22}$ The Times, March 22, 1886, 3.

${ }^{23}$ Ibid.

${ }^{24}$ Preussische Mitteilungen 93 (December 01, 1891). "English people,” a Hamburg daily wrote in 1898 , "are said to be so precise in their usage of time that they turn up at the station at the very last minute." Neue Hamburger Zeitung, July 7,1898. On German and British levels of impatience, see Oliver Zimmer, "Die Ungeduld mit der Zeit". On how the spread of the telegraph heightened a spirit of competition, see Jean-Michel Johnston, „The Telegraphic Revolution: Speed, Space and Time in the Nineteenth Century,“ German History (forthcoming 2019).

${ }^{25}$ Altonaer Nachrichten, August 01,1883.

${ }^{26}$ Allgemeine Zeitung, October 29, 1889.

${ }^{27}$ Hamburger Nachrichten, November 16,1889

${ }^{28}$ Allgemeine Zeitung, March 26, 1890.

${ }^{29}$ Allgemeine Zeitung, April 16, 1891.

${ }^{30}$ Altonaer Nachrichten, February 13,1892.

${ }^{31}$ Allgemeine Zeitung, October 5,1891. The difference between Aachen and Königsberg was circa 55 minutes. For a table indicating the difference between MEZ. and various 
German towns, see Bayerisches Jahrbuch. Kalender für Bureau, Comptoir und Haus, Vierter Jahrgang (1893): 54.

${ }^{32}$ Authors of general historical accounts often forget that, in many societies including Germany, Eisenbahnfieber was for some time mainly a spectator sport. According to Siegfried Weichlein, 72,778 Saxons and 53,917 Bavarians travelled by rail every day in 1887; the bulk of passenger traffic was short distance, with only a small minority of travelers crossing the boundary of their state; well into the 1880 s the passenger network remained relatively inaccessible for the majority of the German population. Weichlein speaks of Eisenbahnwüsten and Eisenbahnparadiesen: Weichlein, Nation und Region, 70-72, 94-95. The railways were not alone in this: On the 'two-speed society' created by the telegraph, see Johnston, “The Telegraph Revolution”. As far as the railways' contribution to mass passenger traffic is concerned, the contrast with England remained marked right up to the turn of the century: In 1889, every inhabitant of Germany undertook on average seven journeys by railway per year, which was about a third of the English average. The ratio of 1:3 would remain roughly unchanged for the remainder of the century: In the mid-1890s every English person undertook on average 26.5 train journeys per year. It was 9.1. train journeys per year in France, and in Saxony, the state with the densest railway network in Germany at the time, it was 8.1 journeys in 1887. This draws above all on Timothy Leunig, "Time is Money: A ReAssessment of the Passenger Social Savings from Victorian British Railways," The Journal of Economic History 66 (September 2006): 665. On the changes around 1900, see Zimmer, "Ungeduld mit der Zeit”, 69-80.

${ }^{33}$ The point is made with great force in Pitirim A. Sorokin, Sociocultural Causality, Space, and Time (Durham: Duke University Press, 1943), 197. 
${ }^{34}$ Benedict Anderson, Imagined Communities: Reflections on the Origin and Spread of Nationalism (London: Verso, 1991), 26.

${ }^{35}$ The argument is spelled out more fully in Oliver Zimmer, Remaking the Rhythms, esp. introduction. The conceptual background to this position is developed in Edward S. Casey, "How to get from space to place in a fairly short stretch of time," in Steven Feld, Keith H. Basso, eds., Senses of Place (Santa Fe: School of American Research Press, 1996), 13-52. For a classic treatment see Yi-Fu Tuan, Space and Place: The Perspective of Experience (Minneapolis: University of Minnesota Press, 1977).

${ }^{36}$ Helmuth v. Moltke, “Gesammelte Schriften und Denkwürdigkeiten,” 38-39.

${ }^{37}$ Altonaer Nachrichten, March 4,1893.

${ }^{38}$ Geheimes Staatsarchiv Preussischer Kulturbesitz (GStAPK), I. HA Rep 93E, nr. 1230, Präsident d. Staatsministeriums, von Caprivi, an den K. Staatsminister der öffentlichen Arbeiten, von Maybach, April 20, 1891.

${ }^{39}$ GStAPK. I. HA, Rep 93E, nr. 1230. Dr v. Botticher an Thielen, December 7, 1891.

${ }^{40}$ Bayrisches Hauptstaatsarchiv (BHStA), MVI, nr. 1301, „Die Zonenzeit. Eine Stimme aus dem Publikum“, 1900.

${ }^{41}$ GStAPK, I. HA Rep 93E, nr. 1230, von Caprivi an Thielen, November 23, 1891.

${ }^{42}$ GStAPK, I. HA, Rep 93E, nr. 1230, Sitzung des K. Staatsministeriums, February 2,1892 .

${ }^{43}$ GStAPK, I. HA, Rep 93E, nr. 1230, Ministerium des Geistlichen, Unterrichts- und Medizinalangelegenheiten an K. Staatsminister und Minister für öffentliche Arbeiten, December 21, 1891.

${ }^{44}$ GStAPK, I. HA, Rep 93E, nr. 1230, Ministerium für Handel \& Gewerbe an K. Staatsministerium, November 27, 1891. 
${ }^{45}$ Börsen-Halle, March 25,1884.

${ }^{46}$ Wilhelm Foerster, "Über die von der Conferenz zu Washington proponierte Veränderung des astronomischen Tagesanfanges, “ Astronomische Nachrichten, no. 2643 (January 1884): 35. And, by the same author, Weltzeit und Ortszeit im Bunde gegen die Vielheit der sogenannten Einheits- oder Zonen-Zeiten (Berlin: Ferdinand Dümmlers Verlagsbuchhandlung, 1891). See also E. J. Boettcher, „Nationalzeit, örtliche oder Weltzeit?“'Vortrag, Gemeinnützige Gesellschaft in Leipzig, March 29, 1889, in: Grenzboten 48 (1889): 324-326.

${ }^{47}$ Hamburger Nachrichten, November 5,1890.

${ }^{48}$ Gerhard Dohrn-VanRossum, Die Geschichte der Stunde. Uhren und Moderne Zeitordnunge (Munich: Hanser, 1997), 251. See also Carlo M. Cipolla, Clocks and Culture, $1300-1700$ (New York: W. W. Norton, 1978).

${ }^{49}$ Dohrn-van Rossum, Geschichte der Stunde, 317. Jerrold Siegel considers the "advent of the railroads” the „,most powerful force in establishing modern ways of reckoning time." Siegel, Modernity and Bourgeois Life, 33. For a contemporary perspective, see Schmoller, "Über den Einfluss der heutigen Verkehrsmittel," 413-430.

${ }^{50}$ Dohrn-van Rossum's dichotomy between the time of the town and the time of transportation seems born of an analytical conviction aptly captured by Michel de Certeau: "that a certain kind of production... can set out to produce history by 'informing' the whole of a country." Michel de Certeau, The Practice of Everyday Life (Berkeley: University of California Press, 1984), 167. On page 111 de Certeau called the railways the "perfect actualization of the rational utopia." The tendency is also evident in Schivelbusch, "Railroad Space and Railroad Time," 34-40. 
${ }^{51}$ Leora Auslaender, "Beyond Words," American Historical Review 110, no. 4 (October 2005): 1017. For an account that focuses on the materiality of clocks and their uses, see Smith, Mastered by the Clock. On the importance of ordinary objects in sustaining German nationhood, see Helmut Walser Smith, "Monuments, Kitsch, and the Sense of German Nation in Imperial Germany," Central European History 49 (December 2016): $322-340$.

${ }^{52}$ Allen, A Republic in Time, 66.

${ }^{53}$ Mark M. Smith has put it best in his social history of clock time in the antebellum South: "For plainly, there are points at which various forms of time accommodate one another." Smith, Mastered by the Clock, 40.

${ }^{54}$ Augsburger Tagblatt, February 3, 1836, no. 34. On the replacement of solar moon by mean times in Bavaria, see Staatsarchiv Bamberg (StaBa), F VIII, no. 103, StaatsMinisterium des Innern an die K. Regierung des Obermain-Kreises, Kammer des Innern. Die Regulierung der öffentlichen Uhren nach der mittleren Zeit betreffend, April 2, 1837.

${ }^{55}$ Allgemeiner Anzeiger und Nationalzeitung der Deutschen, October 22, 1842. On the significance of church bells in the French countryside, see Alain Corbin, Village Bells: Sound and Meaning in the Nineteenth-Century French Countryside (New York:

Columbia University Press, 1998), 21.

${ }^{56}$ Allgemeiner Anzeiger und Nationalzeitung der Deutschen, October 22, 1842.

${ }^{57}$ Münchner Tagblatt, July 21,1842.

${ }^{58}$ Augsburger Tagblatt, February 6, 1849.

${ }^{59}$ StaBa, F VIb, no. 4719, Generaldirektion d. K. Bayrischen Verkehrsanstalten an die K. Bayr. Regierung von Oberfranken, Kammer des Innern. Betreff: Die Regulierung der 
Uhren der K. Verkehrsanstalten nach der Münchner mittleren Zeit betreffend, February 2,1854 .

${ }^{60}$ On Augsburg's built environment, see Günther Grünsteudel, Günter Hägele and Rudolf Frankenberger, eds., Augsburger Stadtlexxikon, $2^{\text {nd }}$ edn. (Augsburg: Perlach Verlag, 1998).

${ }^{61}$ Augsburger Tagblatt, June 15, 1856.

${ }^{62}$ Augsburger Anzeigenblatt, January 31, 1858; Augsburger Tagblatt, June 9, 1860.

${ }^{63}$ Augsburger Tagblatt, June 6, 1860.

${ }^{64}$ Augsburger Tagblatt, June 9, 1860.

${ }^{65}$ Augsburger Anzeigeblatt, January 31,1862.

${ }^{66}$ Augsburger Tagblatt, January 6, 1867.

${ }^{67}$ Ansbacher Morgenblatt für Stadt und Land, March 13,1851, 202.

${ }^{68}$ Bayerische Landbötin, October 14, 1848, no. 124. The practice of two-minute hands, one displaying local and one railway time, was widespread in England in the first years after GMT was adopted. See Derek Howse, Greenwich Time and the discovery of longitude (Oxford: Oxford University Press, 1980), 105-112.

${ }^{69}$ Deutsche Blätter, nr. 39, January 1, 1865. Particularly when it comes to large towns and cities, complaints about a lack of electrical clocks was a transnational phenomenon. For a London example, see Punch, November 22, 1851, 228, where an article entitled "Electrical Clocks" began thus: 'In Berlin they have Electrical Clocks - and in Stockholm, all the public clocks are put in motion by electricity. Why could not the same plan be adopted in London?'. See also Gay, “Clock Synchrony,”, 113-117; Galison, “Einstein's Clocks,” 360-361; Michael J. Sauter, “Clockwatchers and 
Stargazers: Time Discipline in Early Modern Berlin,”, American Historical Review 112, no. 3 (June 2007), 685-709.

${ }^{70}$ Amberger Tagblatt, August 6, 1864. In the society that pioneered railway commuter traffic, too, the railways heightened the debate about the accuracy of clocks. See Oliver Zimmer, "Time Tribes: Time and the Other in Britain's Railway Age," ms.

${ }^{71}$ Uhrzeiten. Die Geschichte der Uhr und ihres Gebrauchs (Frankfurt: Jonas Verlag, 1989), 100. An acute insight into the maintenance requirements of a good pocket watch can be gained from a talk delivered at the Technische Gesellschaft Zurich in 1874. J. Schilling-Baumann began with the observation that "the more exquisite pocket watches," provided they were "well maintained and regularly used," would display the time "almost accurately." What constituted good maintenance according to SchillingBaumann was that the watch would be wound-up "slowly and without strong external movements every morning;" that it would be placed in the exact same position every night before going to bed; that during the cold season the watch would not be placed on material such as marble, as excessive differences in temperature would decrease its accuracy; that, to prevent dust from entering the encasement, trouser pockets would "be turned inside out and cleaned from time to time" (the more microscopic the dust, the greater risk it posed to the watch's internal organs); and that, finally, no other items should be put in the pocket in which the watch was carried, least of all keys and coins, as they could break the watch's cover glass. To this Schilling-Baumann added: Every watch, however good its quality, would need to be cleaned and repaired after two to three years. Unless the watch owner knew a skilled watchmaker, it was best to put the watch out of circulation until a trusted professional could be found. When it came to the required setting of one's pocket watch, "tower and electrical clocks" could be "a source 
of deception". It was therefore important to find a trustworthy public clock, and ensure that its movements remained regular over longer periods of time. J. Schilling-Baumann, Uhren im Allgemeinen, deren Geschichte und Behandlung, Separat-Abdruck aus dem Jahresbericht der Technischen Gesellschaft in Zürich, 1875, 11-15, 16-17.

${ }^{72}$ See Daniel Drascek, ,'Früh um 6 Uhr habe ich schon nahezu 24 Stunden Verspätung...' - Zur Verbreitung der Armbanduhr und die zeitliche Rhythmisierung des Alltags um 1900,“ Rheinisches Jahrbuch für Volkskunde 33 (1999/2000): 51-66. ${ }^{73}$ The best works on this theme have been done on the United States, though even there the station clock has not been subject to a separate study. See in particular O'Malley, Keeping Watch, ch. 1; McCrossen, Marking Modern Times, ch. 5.

${ }^{74}$ See Weichlein, Nation und Region, 70-74.

${ }^{75}$ Here as elsewhere, the distinction between towns and cities on one hand, and more rural areas on the other, makes more sense than differentiations according to region, or between Prussia and the rest.

${ }^{76}$ Neue Hamburger Zeitung, June 6, 1903.

${ }^{77}$ StABa, F VIb, no. 4619. Bayreuth an sämtliche Distriktpolizeibehörden, February 20, 1854.

${ }^{78}$ Fürther Tagblatt, November 18, 1873; Kemptner Zeitung, October 3, 1873.

${ }^{79}$ In 1873 , the town authorities of Kempten in Swabia published the following announcement in the Kemptner Zeitung: "Announcement. We herewith wish to bring to public attention that the undersigned authority has ensured that as of today the local clocks - which hitherto have been much in advance of the station clock - will be brought in precise agreement with the station clock." Kemptner Zeitung, October 4, 1873. 
${ }^{80}$ Bamberger Zeitung, June 12, 1865.

${ }^{81}$ Ibid.

${ }^{82}$ Reglement für die Kgl. Schauspiele zu Berlin (Berlin: Schnellpressendruck von E. Litfass, 1852), 44.

${ }^{83}$ Juristische Wochenschrift für die preußischen Staaten, vierzehnter Jahrgang,1848, $355-356$.

${ }^{84}$ Allgemeine Gerichtszeitung. Zeitschrift für Gesetz und öffentliches Recht no. 1.

Berlin, January 2, 1850, 230-233.

${ }^{85}$ On the continued importance of bells for communicating time in the nineteenth century, see Corbin, Village Bells, introduction.

${ }^{86}$ Zeitschrift für die freiwillige Gerichtsbarkeit und Gemeindeverwaltung. 32. Jahrgang, 1890, 136-139.

${ }^{87}$ Mecklenburg-Schwerinsches Landesstrafrecht: die in den Grossherzogthümern Mecklenburg, einschliesslich des Fürstenthums Ratzenburg, in Geltung befindlichen landesrechtlichen Verordnungen strafrechtlichen Inhalts. Schwerin i.M. 1887.

${ }^{88}$ Gesetzsammlung der freien Hansestadt Hamburg, vols. 1 (1866), 175; 11 (1875), 133; 23 (1887), 164; 32 (1895), 72.

${ }^{89}$ Zeitschriftf. Staats- und Gemeindeverwaltung im Grossherzogtum Hessen, vol. VIII. $1884,111$.

${ }^{90}$ Sammlung $d$. Ortsgesetze, Regulative und wichtigeren Polizeiverordnungen für die Grossherzoglich Sächsische Haupt- und Residenzstadt Weimar, 3. Folge, 1910, 168, 181.

${ }^{91}$ Berliner Börsenzeitung, January 10, 1889.

${ }^{92}$ Berliner Börsenzeitung, January 10, 1889. 
${ }^{93}$ GStAPK, I. HA Rep 93E, nr. 1230, Eisenbahndirektion Elberfeld to Minister der öffentlichen Arbeiten, December 23, 1891.

${ }^{94}$ GStAPK, I. HA Rep 93E, nr. 1230, Eisenbahndirektion Breslau to Minister der öffentlichen Arbeiten, February 2, 1892.

${ }^{95}$ GStAPK, I. HA Rep 93E, nr. 1230, K. Eisenbahndirektion Berlin an Minister der öffentlichen Arbeiten, January 14, 1892.

${ }^{96}$ Neue Hamburger Zeitung, March 18, 1899.

${ }^{97}$ Neue Hamburger Zeitung, June 6, 1903.

${ }^{98}$ Die Landgemeinde, Volkstümliche Fachzeitschrift für die ländlichen

Selbstverwaltungs-Behörden und-Beamten der preussischen Monarchie. Amtliches Organ d. Verbandes der altpreussischen Landgemeinden, 1898, 166.

${ }^{99}$ Neue Hamburger Nachrichten, October 28, 1908.

${ }^{100}$ Berliner Börsenzeitung, December 30, 1910. 